Diabetologia 10,697-701 (1974)

(C) by Springer-Verlag 1974

\title{
Metabolism of Genetically Obese Rats on Normal or High-Fat Diet
}

\author{
D. Lemonnier, R. Aubert, J.-P. Suquet and G. Rosselin \\ Laboratoire de Nutrition Humaine de l'Institut Scientifique et Technique de l'Alimentation, et Unité de Recherche de \\ Diabétologie et d'Etudes Radioimmunologiques des Hormones Protéiques, U.55 I.N.S.E.R.M., Paris, France
}

Summary. Adult genetically obese fafa rats showed a high level of lipogenesis from glucose in liver but not in adipose tissue; pancreatic content and serum levels of insulin were elevated. Glucose uptake and insulin sensitivity were decreased in muscle. fafa rats and their lean littermates fod a high-fat diet showed increased fat deposits. Serum insulin levels were not significantly affected by diet in either group. The larger the fat cells were, the more actively they utilised glucose; insulin sensitivity was infuenced both by diet and cell size. Control rats made obese by a high caloric diet did not show insulin resistance in muscle. - The data indicate that in adult obesity in these rats, even in the presence of marked hyperinsulinism, increased lipogenesis in adipose tissue is not a prerequisite. Rather, fat storage is a consequence of increased uptake of circulating triglycerides. On a diet rich in carbohydrate, adipose tissue fatty acids were mainly of hepatic origin; on a high-fat diet they were of dietary origin.

Key words: High-fat diet, rat, nutritional obesity, genetic obesity, adipose tissue, liver, muscle metabolism, insulin sensitivity, pancreatic glucagon, pancreatic and plasmatic insulin.
Obesity is associated with hyperinsulinism i.e. increased insulin secretion and high plasma insulin levels. This hyperinsulinism is partly related to a high carbohydrate intake [1]. Long term feeding of a high fat diet to genetically obese $o b o b$ mice (a) markedly increases their obesity, (b) has no effect on their hyperglycemia, but (c) decreases serum insulin levels [2]. Moreover, obesity can be induced in lean animals by feeding a high-fat-low-carbohydrate diet given ad lib. [3]. This kind of experimental obesity is characterized by normal levels of circulating insulin in vivo, and in vitro by a decreased insulin response to glucose [4]. These data indicate that obesity per se is not closely related to hyperinsulinism.

In the present investigation, genetically obese fafa rats were studied. They are known to present with a high degree of hyperinsulinism $[5,6]$, high levels of serum lipids [7] and an elevated lipogenesis of adipose tissue [8]. The aim of the study was to investigate the

\section{Materials and Methods}

Five month old male genetically obese fafa rats [7] and their lean littermates $(\mathrm{FaFa}$ or Fafa) were fed $a d$ lib for 7 months either a control diet $\mathrm{T}$ ( $9 \%$ of calories as lipid, $22 \%$ as protein, and $69 \%$ as carbohydrate), or a high-fat $(72 \%$ of calories as lipid, $22 \%$ as protein, and $16 \%$ as carbohydrate) diet S [3]. Four groups of rats were obtained. Animals were killed by decapitation in the fed state in the morning. Blood was collected and serum glucose was assayed by the glucose oxidase method (Boehringer Mannheim Test). Serum insulin was measured by the method of Rosselin et al. [9]. The pancreatic content of insulin was determined as previously described [4]. Pancreatic glucagon was assayed according to Jarrousse et al. [10].

The incorporation of glucose- $\mathrm{U}^{14} \mathrm{C}$ into $\mathrm{CO}_{2}$, lipids or glycogen in liver slices, hemidiaphragms and peri-

Table 1. Pancreatic insulin and glucagon, serum insulin and glucose of lean Fa or genetically obese fa rats fed a control $T$ or a high-fat diet $S$. The animals were maintained for 7 months on the diets $T$ or $S$ until the age of 12 months, time of sacrifice

\begin{tabular}{|c|c|c|c|c|c|c|c|}
\hline Groups & $n$ & $\begin{array}{l}\text { Body } \\
\text { weight } \\
\left(\mathrm{g}^{4}\right)\end{array}$ & $\begin{array}{l}\text { Serum } \\
\text { glucose } \\
(\mathrm{mg} / 100 \mathrm{ml})\end{array}$ & $\begin{array}{l}\text { Serum } \\
\text { insulin } \\
(\mu \mathrm{U} / \mathrm{ml})\end{array}$ & $\begin{array}{l}\text { Pancreatic } \\
\text { weight } \\
(\mathrm{mg})\end{array}$ & $\begin{array}{l}\text { Stored insulin } \\
\text { (U per pancreas) }\end{array}$ & $\begin{array}{l}\text { Stored glucagon } \\
\text { ( } \mu g^{*} \text { per } \\
\text { pancreas) }\end{array}$ \\
\hline Fa T & 8 & $530 \pm 12.2$ & $132 \pm 5.6$ & $138 \neq 11.5$ & $1404 \pm 77.7$ & -0.149 & $8.37+0.440$ \\
\hline $\mathrm{Fa} \mathrm{S}$ & 9 & $566 \pm 16.1$ & $119 \pm 3.8$ & $167 \pm 42.3$ & $1341 \pm 65.2$ & $1.48 \pm 0.185$ & $7.06 \pm 0.293$ \\
\hline$f a \mathrm{~T}$ & 6 & $672 \pm 36.4$ & $134 \pm 4.7$ & $536 \pm 101$ & $1314+97.5$ & $3.22+0.549$ & $5.22+0.400$ \\
\hline$f a \mathrm{~S}$ & 6 & $885 \pm 31.0^{b}$ & $121 \pm 3.1$ & $422 \pm 69.9$ & $1414 \pm 64.0$ & $3.15 \pm 0.387$ & $6.58 \pm 0.386^{\mathrm{a}}$ \\
\hline
\end{tabular}

a $(p<0.05)$ and ${ }^{b}(p<0.01)$ degree of statistical significance in differences versus the corresponding control group (Fa $\mathrm{T}$ or $f a \mathrm{~T}$ ).

locus of fat synthesis in the obese animals and their lean littermates, and the possible influence of different diets. Special attention was given to the role of insulin and of fat cell size in this model of hereditary and/or dietary obesity. genital adipose tissue pieces, was measured as described elsewhere [11]. Insulin $(1 \mathrm{mU} / \mathrm{ml})$ was added to the incubation medium in the case of adipose tissue and muscle. Measurements of adipose tissue cellularity have been described [3]. 


\section{Results}

Body weight was significantly increased by the combination of high-fat diet and the obesity genes of fafa rats (Table 1).

Serum glucose tended to decrease slightly in rats on high fat diet. Pooling obese ( $f a f a$ ) and nonobese ( $\mathrm{FaFa}$ ) type rats, the high fat diet reduced blood glucose levels significantly $(p<0.01)$. Serum insulin was not significantly changed by high fat diet. The most striking observation was a four-fold increase in circulating insulin levels in the obese group on control diet.

As shown in Table 1, the pancreas of obese rats contained twice as much insulin as those of lean animals $(p<0.01)$; this was not affected by diet. Pancreatic glucagon content was similar in all groups.

\section{Adipose Tissue Metabolism}

Fat cell volume was 2.2 fold increased in the epididymal adipose tissue of genetically obese animals regardless of diet composition. In the lean rats however, high fat diet induced a $50 \%$ increase in fat cell volume above control. Changes in cell number were not observed in this site [12]. Fig. 1 shows the basal incorporation of glucose $-\mathrm{U}^{14} \mathrm{C}$ into $\mathrm{CO}_{2}$, total glycerol and total fatty acids (FA) of adipose tissue fragments. All results are expressed per fat cell. Total dpm recovered as ${ }^{14} \mathrm{CO}_{2}$ and labeled lipids were twice as high $(p<0.01)$ in the obese rats indicating an increased glucose uptake in these animals. High fat diet increased this value as well $(p<0.01)$ but to a lesser extent. Whereas FA incorporated only $5-10 \%$ of total ${ }^{14} \mathrm{C}$ uptake, the bulk of radioactivity was found in the glycerol moiety. Fig. 1 also shows that in the basal state, labeled glycerol was augmented by both genetic obesity and high fat diet. By contrast, ${ }^{14} \mathrm{C}$ incorporation into FA was increased only by genetic obesity, but not by diet.

The effect of insulin added in vitro $(1 \mathrm{mU} / \mathrm{ml})$ was most marked for FA synthesis (Fig. 1e). Adipose tissue of animals on control diet was significantly $(p<0.05)$ more responsive. The same was true for ${ }^{14} \mathrm{CO}_{2}$ production. By contrast, insulin-induced glycerol synthesis was insignificant whatever the group. When the results were related to fat cell surface, most of these differences were maintained.

\section{Liver Metabolism}

Fig. 2 shows ${ }^{14} \mathrm{C}$-glucose incorporation into $\mathrm{CO}_{2}$ and phospholipids as well as into the glycerol and FA moieties of tissue triglyceride (TG) of incubated liver slices. Most of the label was recovered in $\mathrm{CO}_{2}$ and the bulk of changes in glucose uptake was reflected in alteration of FA synthesis (Fig. 2d).

High fat diet had an impressive effect as it reduced glucose uptake into TG-FA by $\mathbf{9 0} \%$. All other parameters measured were reduced by this diet. Genetic obesity, by contrast, markedly increased glucose uptake into liver tissue.

\section{Muscle Metabolism}

Glucose uptake and its conversion into $\mathrm{CO}_{2}$ and/or glycogen of hemi-diaphragms are depicted in Fig. 3. About $9 / 10$ of glucose taken up was converted into glycogen.

In the basal state it appears clear that fat diet and to a lesser extent genetic obesity decreased all three: glucose uptake, $\mathrm{CO}_{2}$ production and glycogen synthesis $(p<0.01)$. Glucose uptake and glycogen synthesis in diaphragms of fafa rats were not further reduced by fat diet.
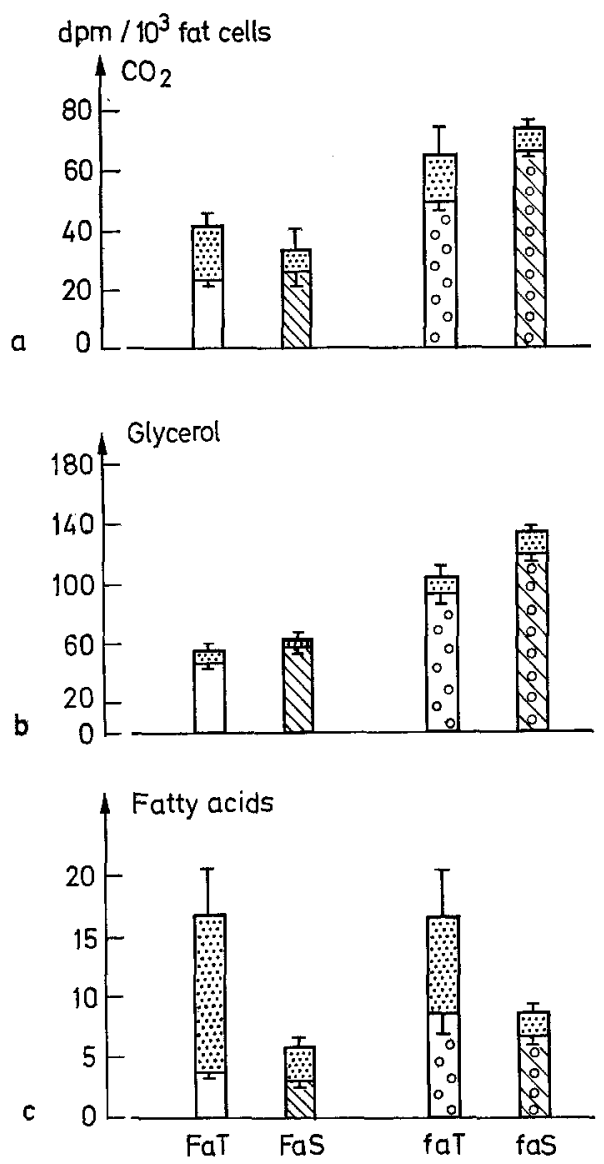

Fig. 1. Glucose $\mathrm{U}^{14} \mathrm{C}$ incorporation into $\mathrm{CO}_{2}$ (a), total glycerol (b), total fatty acids (c) of adipose tissue fragments incubated with 0 or without insulin $(1 \mathrm{mU} / \mathrm{ml})$. Mean \pm SEM. $\square$ lean control rats; 0 genetically obese rats; $\mathbb{Q}$ rats fed a high-fat diet $\mathrm{S}$. Fat cell volume $\left(10^{3} \mu^{3}\right)$ and number of rats in each group: Fa T: $766 \pm 73$ (8); Fa S: $1114 \pm 143(7) ; f a \mathrm{~T}: 1673 \pm 139(6) ; f a \mathrm{~S}: 1663 \pm 55$ (6)

The addition of $1 \mathrm{mU}$ insulin per $\mathrm{ml}$ of medium increased glucose uptake and glycogen synthesis in all groups. The effect of insulin on musele was reduced by obesity but not by diet. 


\section{Discussion}

The cause of obesity is still poorly understood. Various animal models have been studied to shed light onto possible pathogenic mechanisms. The present study deals with the obesity of the genetically obese fafe rats and the influence of diet composition.

As Table 1 shows, the genetically obese animals were heavier than their lean siblings. A diet with a
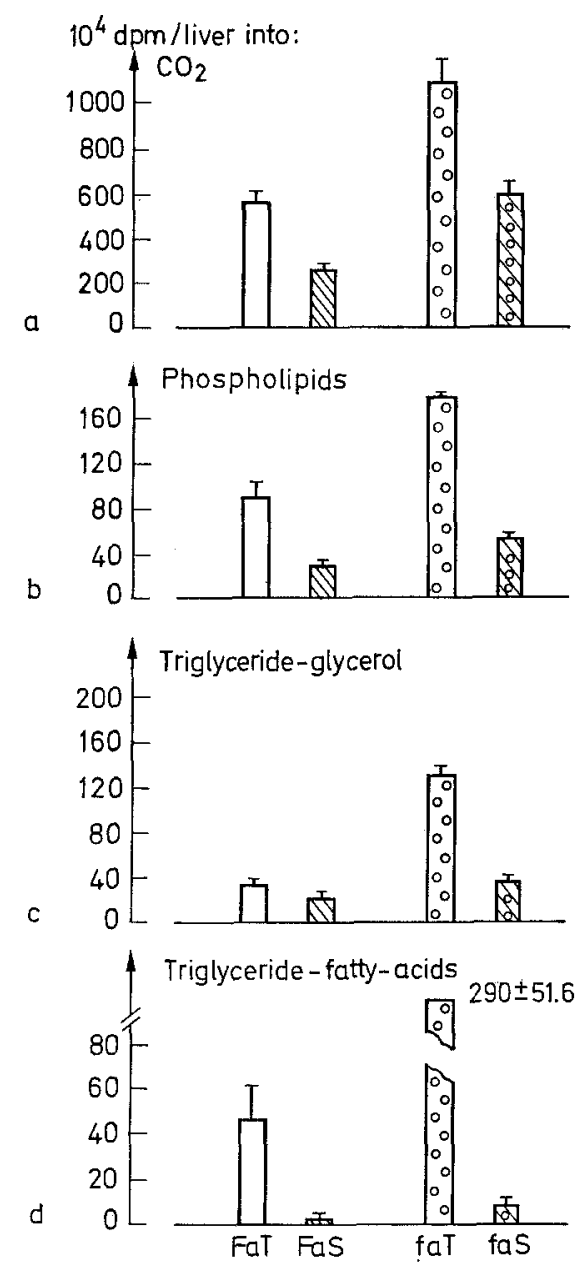

Fig. 2. Glucose $\mathrm{U}^{14} \mathrm{C}$ incorporation into $\mathrm{CO}_{2}$ (a), phospholipids (b) and triglycerides (c, d) of liver slices incubated in vitro. Mean \pm SEM. $\square$ lean controls rats, $\mathbb{N}$ rats on a high fat diet $\mathrm{S}$; 00 genetically obese rats. Weight $(\mathrm{g})$ of the livers, $\left(\mathrm{n}^{\circ}\right.$ of rats in each group): Fa T 17.3 $\pm 0.65(7)$;

Fa S $15.3 \pm 0.52(8) ; f a$ T $24.1 \pm 2.61$ fa S $23.3 \pm 0.90$

high fat content increased not only the fat stores of the genetically obese, but also of the lean rats [12]. Thus, body weight appears to be influenced by at least two factors, the genetic background and the composition of the diet. Similar results have been described in obob mice [2]. Studies done with Swiss mice and Wistar rats showed a more marked effect of diet $[3,13]$, partly because in those animals, the diet was begun earlier in life than in the present study $[13,14]$.

In order to analyse the possible mechanisms involved in the pathogenesis of obesity in these fafa rats, the three main organ systems involved in diabetic metabolism have been studied in vitro, namely adipose tissue, muscle and liver.

Adipose tissue of the adult genetically obese rats showed a much higher glucose uptake, the bulk of
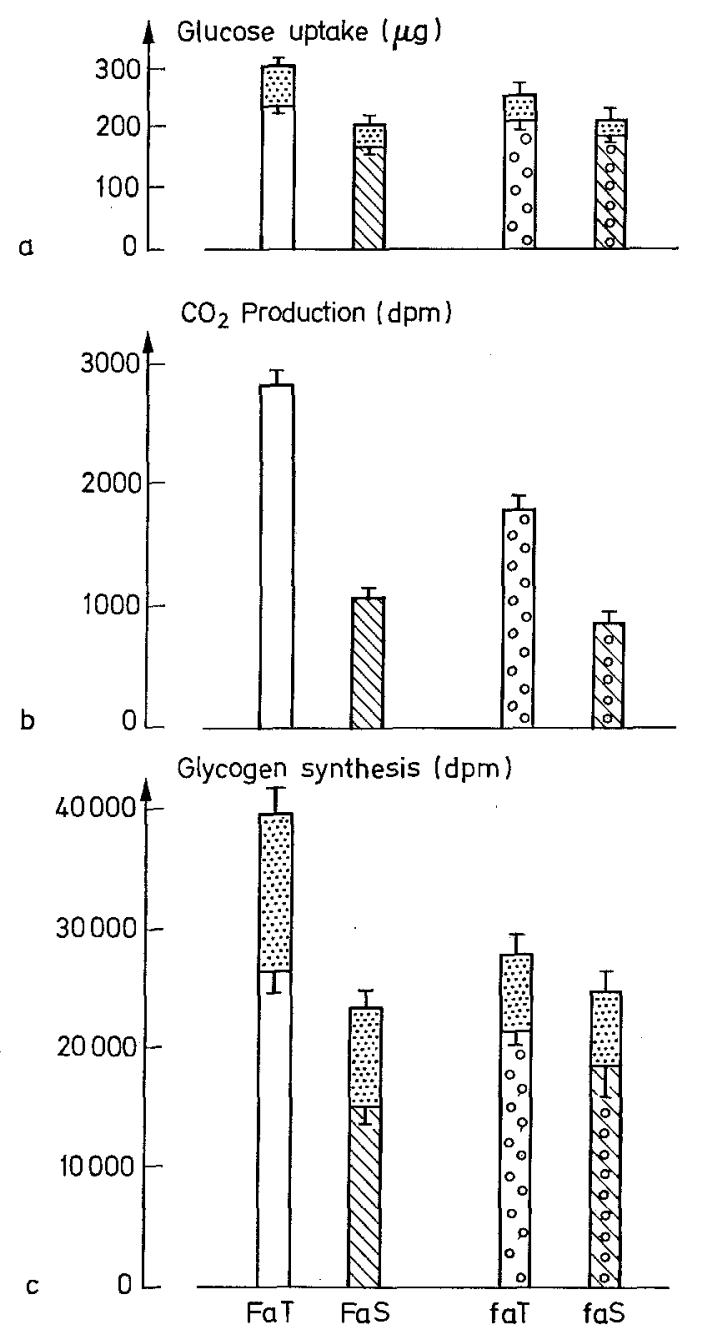

Fig. 3. Glucose uptake and glucose $\mathrm{U}^{14} \mathrm{C}$ incorporation into $\mathrm{CO}_{2}$ and glycogen per $\log _{10} 100 \mathrm{mg}$ of hemidiaphragms incubated with : or without insulin $(1 \mathrm{mU} / \mathrm{ml})$. Mean \pm

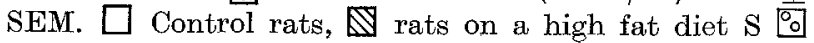
genetically obese rats. Weight $(\mathrm{mg})$ of the 2 hemidiaphragms ( $\mathrm{N}^{\circ}$ of rats): Fa T $741 \pm 43.2(7)$; Fa S $738 \pm 33.7$ (8); fa T $592 \pm 25.5(8) ; f a \mathrm{~S} 675 \pm 15.5(6)$

which was incorporated into glycerol (Fig. 1). FA synthesis was not particularly marked. However, the effect of insulin added in vitro was most striking in increasing FA synthesis and by far the most impressive in the animals (lean or obese genetically) on control diet. In muscle, as one might expect, about $90 \%$ of glucose taken up was incorporated into glycogen. High 
fat diet decreased glucose uptake and, thereby, glycogen synthesis and $\mathrm{CO}_{2}$ production.

Liver slices of genetically obese rats showed a six fold incorporation rate into TG-FA compared to that of lean animals. Therefore, the main site for lipogenesis in adult fafa rats appears to be the liver and not adipose tissue. On the high fat diet, lipogenesis was reduced by more than $90 \%$ in lean and obese animals, indicating that diet is an important regulator of hepatic lipogenesis.

It was of particular interest to study the conditions in vivo which may have influenced the behaviour of the organs in vitro. Hyperinsulinemia appears to be a characteristic of genetically obese fafa rats (Table 1). However, high fat diet reduced serum insulin levels slightly whereas fat stores increased markedly [12]. This may be due partly to the lower carbohydrate intake which could not be avoided with the high fat diet, as long as protein supply had to be constant. It is quite possible that the insulin levels in vivo were directly responsible for the behaviour of the isolated organs in vitro. Indeed, adipose tissue of fafa rats exposed to very high insulin levels in vivo, showed higher rates of glucose metabolism (Fig. 1). This was all the more marked in liver slices where up to sixfold differences could be observed (Fig. 2). The connection between hyperinsulinemia and hepatic lipogenesis has been suggested by Steiner [15] and Letarte [16]. In muscle, interestingly, fafa rats showed less glucose metabolism. By contrast, although no dramatic changes in insulin levels were obtained by feeding the high fat diet, the glucose uptake decreased markedly in liver and muscle tissue. In adipose tissue such an effect was found only for the insulin response in respect to FA synthesis.

Although the main FA synthesis occurs in the liver, $f a f a$ rats have an increased adipose mass where glucose is mainly incorporated into $\alpha$-glycerophos phate to form triglyceride. The FA moiety comes from circulating triglycerides as suggested by the doubled lipoprotein lipase activity found in the fat cells of these fafa rats [17]. A similar argument applies to the higher glucose incorporation into triglyceride glycerol of adipose tissue of obese and lean animals fed the high fat diet, i.e. the increased supply of FA (in this case from exogenous sources) needed more $\alpha$-glycerophosphate for triglyceride synthesis. Thus, feeding a high fat diet seems to speed the effects of ageing [18]. Fatty acid composition of adipose tissue reveals that dietary fatty acids are stored as such in adipose tissue [11]. Human studies with adult obese and lean subjects have lead to similar conclusions: lipogenesis is unsignificant in adipose tissue $[19,20]$.

The role of fat cell size deserves special consideration. Since fafa rats have adipocytes of twice the volume of lean rats, one might implicate this fact in the higher glucose uptake of fafa adipose tissue. Indeed, when adipocytes of lean rats were increased in volume by high fat diet, glucose uptake of adipose tissue in vitro was equally increased. Similar results have been obtained by Smith in human obesity [20] and by Stern in fafa rats [21]. An additional increase of glucose utilisation was observed in the fafa rat fed a high-fat diet although cell size did not change any further. Insulin resistance has been suggested to be related to the increased fat cell size by a decreased number of binding sites [22]. The present data confirm this argument in part: in vitro added insulin had a smaller effect on tissue of $f a f a$ rats which have larger adipocytes. However, although high fat diet increased fat cell size and decreased insulin sensitivity in the lean rats, in the obese rats the insulin effect was diminished by high fat diet with no further change in fat cell size. It appears, therefore, that basal glucose uptake and insulin sensitivity are not dependent on fat cell size only.

In conclusion, the data presented here show the importance of diet composition in relation to obesity of genetically obese fafa rats. In adults the bulk of adipose tissue FA appears to derive from either dietary fatty acids or from fatty acids synthetized in the liver. Hyperinsulinemia is probably an important factor contributing to obesity in this animal as well as to insulin resistance in muscle. Also, fat cell size induced by either genetic background or by high fat diet appears to be related to increased glucose metabolism and partly to insulin resistance.

Acknowledgements. This work was supported in part, by Research grants (Contrat Libre 71.5.219.12) from the Institut National de la Santé et de la Recherche Médicale (France).

The authors are indebted to Claudine Boissard, André Alexiu and Robert Loeb for their expert technical assistance. They are most grateful to Dr. A. E. Renold and Dr. W.A. Muller for their precious advice and help in the preparation of the manuscript.

\section{References}

1. Grey, N., Kipnis, D.M.: Effect of diet composition on the hyperinsulinemia of obesity. New Engl. J. Med. 285, 827 (1971)

2. Lemonnier, D., Winand, J., Furnelle, J., Christophe, J.: Effects of a high-fat diet on obese-hyperglycomic and non-obese Bar-Harbor mice. Diabetologia 7, 328 (1971)

3. Lemonnier, D.: Effect of age, sex and site on the cellularity of the adipose tissue in mice and rats rendered obese by a high-fat diet. J. clin. Invest. 51, 2907 (1972)

4. Malaisse, W.J., Lemonnier, D., Malaisse-Lagae, F., Mandelbaum, I.M.: Secretion of and sensitivity to insulin in obese rats fed a high-fat diet. Horm. Metab. Res. 1, 9 (1969)

5. Zucker, I.M., Antoniades, H.N.: Insulin and fattening in the genetically obese-hyperlipemic rat "fatty". Fed. Proc. 29, 379 (1970)

6. Lemonnier, D.: Hyperinsulinism in genetically obese rats. Horm. Metab. Res. 3, 287 (1971)

7. Zucker, L. M.: Hereditary obesity in the rat associated with hyperlipemia. Ann. N.Y. Acad. Sci. 131, 447 (1965) 
8. York, D.A., Bray, G.A.: Adipose tissue metabolism in six week old fatty rats. Horm. Metab. Res. 5, 355 (1973)

9. Rosselin, G., Dolais, J.: Application de la méthode radioimmunologique au dosage de l'insuline humaine et au dosage de l'hormone folliculo-stimulante humaine (HFSH). Dans: Les Isotopes - Applications biochimiques. 1 vol. Paris: Expansion Scient. 1967

10. Jarrousse, C., Rancon, F., Rosselin, G.: Hormonogénèse périnatale de l'insuline et du glucagon chez le rat. C.R. Acad. Sci. (Paris) 276, 585 (1973)

11. Lemonnier, D., Aubert, R., Suquet, J.-P., de Gasquet, P., Pequignot, E., Christophe, J., Winand, J.: Metabolic changes induced by a high-fat diet on adipose tissue, liver and muscle of the genetically obese fafa rat. (to be published)

12. Lemonnier, D., Alexiu, A.: Cellularité du tissu adipeux du rat obèse génétique fafa. Effet d'un régime hyperlipidique. J. Physiol. (Paris) 67, 205 A (1973)

13. Lemonnier, D.: Obésité par des régimes hyperlipidiques chez le rat et la souris. Nutr. et Dieta. (Basel) 9, 27 (1967)

14. Mickelsen, O., Takahashi, S., Craig, C. : Experimental obesity. I. Production of obesity in rats by feeding high-fat diets. J. Nutr. 57, 541 (1955)

15. Steiner, D.F.: Insulin and the regulation of hepatic biosynthetic activity. Vitam. and Horm. 24, 1 (1966)

16. Letarte, J., Fraser, T.R.: Stimulation by insulin of the incorporation of $\mathrm{U}^{14} \mathrm{C}$ glucose into lipids released by the liver. Diabetologia 5, 358 (1969)
17. de Gasquet, P., Pequignot, E., Lemonnier, D., Alexiu, A.: Adipose tissue lipoprotein lipase activity and cellularity in the genetically obese Zucker rat ( $f a f a$ ). Biochem. J. 132, 633 (1973)

18. di Girolamo, M., Rudman, D.: Variations in glucose metabolism and sensitivity to insulin of the rat's adipose tissue, in relation to age and body weight. Endocrinology 82, 1133 (1968)

19. Mellati, A.M., Beck, J.-C., Dupré, J., Rubinstein, D.: Conversion of glucose to lipid by human adipose tissue in vitro. Metabolism 19, 988 (1970)

20. Smith, U.: Effect of cell size on lipid synthesis by human adipose tissue in vitro. J. Lipid Res. 12, 65 (1971)

21. Stern, J., Johnson, P.R., Greenwood, M.R.C., Zucker, L.M., Hirsch, J.: Insulin resistance and pancreatic insulin release in the genetically obese Zucker rat. Proc. Soc. exp. Biol. (N. Y.) 139, 66 (1972)

22. Freychet, P., Laudat, M.-H., Laudat, P., Rosselin, G., Kahn, C.R., Gorden, P., Roth, J.: Impairment of insulin binding to the fat cell plasma membrane in the obese hyperglycemic mouse. FEBS Letters 25, 339 (1972)

Dr. Daniel Lemonnier

ISTA-CNAM

292, rue Saint Martin

F-75141 Paris Cedex 03

France

Responsible for the text: Prof. Dr. W. CRedtzfendt, Med. Universitätsklinik, Humboldtallee 1, D-34 Göttingen/F. R. G. Prof. Dr. K. Schöfflisg, Zentrum der Inneren Medizin, Theodor-Stern-Kai 7, D-6 Frankfurt 70/F. R. G. Responsible for advertisements: L. SieGEL, G. Martin, D-1000 Berlin 15, Kurfürstendamm 237. Springer-Verlag, Berlin, Heidelberg, New York. Printed in Germany by aprinta, Wemding/Schwaben. 